\title{
Pengaruh Digital Marketing dan Brand Awareness terhadap Penjualan Produk KartuAS Telkomsel Cabang Palembang
}

\author{
Rofik Satria $^{1)}$, Hasmawaty A.R. ${ }^{2)}$ \\ 1), 2) Universitas Bina Darma, Palembang \\ Email: rofiksatra@gmail.com ${ }^{1)}$
}

\begin{abstract}
The purpose of this research was to determine the effect of digital marketing on the sales product of KartuAS by PT. Telkomsel Branch Palembang, to determine the effect of brand awareness on the sales product of KartuAS by PT. Telkomsel Branch Palembang, to determine the effect of digital marketing and brand awareness on KartuAS sales in Palembang City. The population of this research is the population of the millennial generation in Sukarami Village, Sukarami District, Palembang City for use the KartuAS by PT. Telkomsel as many as 1274 people and the sample as many as 200 people. Samples were taken by random sampling with an error rate of 5\%. Primary data was taken using digital marketing questionnaires, brand awareness questionnaires and product sales questionnaires. Data were analyzed by simple linear regression analysis model and multiple linear regression analysis model. The results show that there is an influence of digital marketing on product sales, there is an influence of brand awareness on product sales, and there is a joint influence of digital marketing and brand awareness on product sales.
\end{abstract}

Keywords: digital marketing, brand awareness, product sales

\begin{abstract}
Abstrak
Tujuan penelitian ini adalah untuk mengetahui pengaruh digital marketing terhadap penjualan produk KartuAS PT. Telkomsel Branch Palembang, untuk mengetahui pengaruuh brand awareness terhadap penjualan produk KartuAS PT Telokmsel Branch Palembang, dan untuk mengetahui pengaruh digital marketing dan brand awareness terhadap penjualan KartuAS di Kota Palembang. Pupulasi penelitian ini adalah penduduk generasi milenial di Kelurahan Sukarami Kecamatan Sukarami Kota Palembang yang memakai produk kartu AS dari PT. Telkomsel sebanyak 1274 orang dan yang dijadikan sampel sebanyak 200 orang. Sampel diambil secara random sampling dengan taraf kesalahan 5\%. Data primer diambil dengan menggunakan kuisioner digital marketing, kuisioner brand awareness dan kuisioner penjualan produk. Data dianalisis dengan model analisis regresi linier sedarhana dan model analisis regresi linier berganda. Hasil penelitian menunjukan bahwa ada pengaruh digital marketing terhadap penjualan produk, ada pengaruh brand awareness terhadap penjualan produk, dan ada pengaruh bersama-sama digital marketing dan brand awareness terhadap penjualan produk.
\end{abstract}

Kata Kunci: digital marketing, brand awareness, penjualan produk

\section{Pendahuluan}

Dalam masa pandemi covid-19 terjadi pergeseran konfigurasi penggunaan internet di Indonesia. Sebelum masa pandemi covid-19, penggunaan internet lebih banyak di perkantoran, kampus, sekolah, dan area publik. Dalam masa pandemi covid-19 ini, konfigurasi penggunaan internet bergeser ke perumahan atau wilayah permukiman. Hal tersebut terjadi sebagai kosekuensi dari himbauan pemerintah untuk bekerja dari rumah dan belajar dari rumah (Kominfo.go.id, 2020). Keharusan untuk bekerja dari rumah dan belajar dari rumah tersebut meningkatkan kebutuhan akan layanan internet. Sehubungan dengan peningkatan kebutuhan layanan internet tersebut memicu peningkatan persaingan harga paket seluler. Operator seluler dalam menjaring pelanggan baru semakin inovatif.

Seiring dengan perkembangan teknologi yang sangat pesat membuat pertumbuhan bisnis telekomunikasi, khususnya kartu seluler semakin meningkat, seiring meningkatnya bisnis $e$ - 
commerce di Indonesia, ditandai dengan peningkatan nilai transaksi belanja daring di Indonesia dalam masa pandemi covid-19. Aktivitas daring sekarang ini juga ikut menyumbang meningkatnya penggunaan layanan internet di Indonesia. Banyaknya pelaku bisnis operator seluler yang berekspansi dan menargetkan masyarakat Indonesia sebagai target marketnya karena memiliki potensi yang sangat besar, dilihat dari pertumbuhan pengguna internet di Indonesia yang semakin berkembang dan terus mengalami peningkatan.

Menurut Asosiasi Penyelenggara Jasa Internet Indonesia (APJII) bahwa pada tahun 2020 sekarang ini menunjukan jumlah pengguna internet di Indonesia mencapai 196,7 juta atau 73,7\% dari populasi penduduk Indonesia (Bisnis.com, 2020). Dari total pengguna internet di Indonesia, sebesar 150 juta orang diantaranya menggunakan internet untuk mengakses media sosisl. Hal tersebut menunjukan bahwa mayoritas pengguna internet di Indonesia, telah menggunakan media sosial (Merdeka.com, 2020).

Media sosial atau jejaring sosial adalah media digital yang sering digunakan dalam digital marketing. Hal ini dapat kita lihat dari data sebuah agensi digital marketing di Amerika (wearesocial.com), yang menyebutkan bahwa secara berurutan yaitu Youtube, Facebook, Instagram, Twitter, Whatsapp, dan Google ${ }^{+}$adalah media sosial yang paling banyak digunakan oleh masyarakat Indonesia. Berikut ini merupakan data media sosial yang sering diakses oleh generasi muda Indonesia pada tahun 2020;

Tabel 1. Media Sosial Yang Sering Diakses

\begin{tabular}{|c|l|c|c|}
\hline No & \multicolumn{1}{|c|}{ Media Sosial } & Jumlah Pengguna & Pesentase pengguna \\
\hline 1 & Youtube & 132 juta & $88 \%$ \\
\hline 2 & Whatsapp & 125 juta & $83 \%$ \\
\hline 3 & Facebook & 121 juta & $81 \%$ \\
\hline 4 & Instagram & 120 juta & $80 \%$ \\
\hline 5 & Tiktok & 118 juta & $79 \%$ \\
\hline
\end{tabular}

Sumber : Merdeka.com, 2020

Dari data tersebut dapat diurutkan media sosial yang paling sering digunakan di Indonesia yaitu Youtube sebesar $88 \%$, whatsapp sebesar $83 \%$, facebook sebesar $81 \%$, instagram sebesar $80 \%$, dan Tiktok sebesar $79 \%$, dari persentase tersebut dapat diketahui bahwa perkembangan media sosial di Indonesia memiliki peluang yang besar untuk dijadikan sebagai sebuah media dalam memasarkan produknya. Media sosial sendiri merupakan termasuk digital marketing yang sangat pontensial.

Perkembangan teknologi digital dan internet yang sangat pesat tersebut akan mempengaruhi dunia pemasaran, dimana pemasaran tradisional yang pada awalnya dilakukan dengan manual kemudian berubah menjadi pemasaran secara digital yang dikenal dengan era digital (Aditya dalam Ali Amran, dkk, 2018). Dilihat dari kegiatan pemasaran yang bergeser dari dunia nyata 
ke dunia maya merupakan dorongan dari cepatnya perkembangan teknologi digital serta banyaknya masyarakat yang semakin berbasis pada perangkat canggih dimana pengguna internet dan media sosial yang semakin meningkat setiap waktu, hal tersebut menjadi peluang yang sangat besar bagi perusahaan para pebisnis untuk memasarkan dan menjual produkproduk yang dihasilkannya (Zuhroh, 2010).

Memasarkan suatu merek produk barang maupun jasa, diperlukan media untuk menjangkau target audience. Target audience yang dimaksud adalah para masyarakat digital/pengguna media sosial. Bentuk dari pemasaran ini disebut pemasaran digital (digital marketing). Digital marketing bertujuan untuk menyebarkan informasi, mempengaruhi, mendidik, menghibur, dan mengingatkan audience. Untuk menjangkau para digital society, perusahaan dituntut untuk dapat beradaptasi dengan perkembangan digital agar tidak tertinggal karena Digital marketing sendiri adalah untuk mencapai tujuan pemasaran melalui penerapan teknologi dan media digital (Chaffey, 2016).

Digital marketing adalah sebuah proses berulang dari perbaikan dan penyempurnaan berkelanjutan. Dalam digital marketing bukan hanya membahas mengenai teknologi saja, namun juga berkenaan orang-orang (market). Bagaimana pelaku bisnis (markers) dapat berhubungan dengan pelanggannya (consumers) untuk membangun sebuah hubungan dan mendorong penjualan (Gumilang, 2019).

Digital marketing adalah kegiatan marketing termasuk branding yang menggunakan berbagai media berbasis web seperti blog, website, e-mail, adwords, ataupun jejaring sosial. Hadirnya digital marketing disebabkan oleh majunya perkembangan teknologi informasi yang dibarengi dengan mobile technology. Memanfaatkan mobile technology membuat setiap orang yang memiliki jaringan internet, dapat mendapatkan informasi akurat hanya dalam genggaman (Kazali, 2011). Dalam dunia usaha dewasa ini pemanfaatan mobile teknology sangat diutamakan, termasuk dalam memasarkan produk dari perusahaan tersebut (Sanjaya, R. \& Josua Tarigan, 2009).

Pemasaran atau promosi suatu produk dewasa ini tidak lagi berpusat pada promosi konvensional dengan memanfaatkan media konvensional berupa televisi, radio, dan koran. Dewasa ini telah berkembang promosi produk usaha melalui media sosial. Berikut ini data media sosial yang banyak digunakan untuk promosi produk oleh pelaku usaha di Indonesia pada tahun 2020;

Tabel 2. Media Sosial Yang Populer Untuk Promosi Produk

\begin{tabular}{|c|c|c|c|}
\hline No & Media Sosial & Jumlah Pengguna & Pesentase pengguna \\
\hline 1 & Youtube & 132 juta & $88 \%$ \\
\hline 2 & Facebook & 130 Juta & $87 \%$ \\
\hline 3 & Whatsapp & 124 juta & $83 \%$ \\
\hline 4 & Instagram & 61 juta & $41 \%$ \\
\hline 5 & Twitter & 60 juta & $40 \%$ \\
\hline
\end{tabular}


Sumber : Niagahoster.co.id, 2020

Berdasarkan data di atas, media sosial youtube menempati urutan pertama yang sering digunakan untuk promosi produk. Pada saat sekarang ini persaingan perusahaan semakin ketat dengan adanya berbagai strategi pemasaran, seperti strategi promosi. Namun bukan hanya mempromosikan atribut fungsional produk, melainkan harus dikaitkan dengan sebuah merek (brand), merek merupakan suatu faktor yang terpenting dalam memperkenalkan produk kepada konsumen. Merek juga dapat menciptakan asosiasi terhadap suatu produk agar dapat melekat dibenak konsumen. Dengan memiliki merek, maka produk akan lebih mudah dikenal oleh konsumen dan sebagai alat pembeda satu produk dengan produk yang lainnya.

Kesadaran merek (brand awareness) adalah kekuatan suatu merek dan itu merupakan suatu aset yang dimiliki perusahaan. brand awareness dapat memberikan dampak yang positif bagi perusahaan karena perusahaan mengetahui nama merek tersebut ditanggapi oleh konsumen. Merek yang memberikan suatu kesan akrab dengan konsumen, dan kecenderungan konsumen menyukai sesuatu yang akrab. Membangun kesadaran merek (brand awareness) biasanya dilakukan dalam periode waktu yang lama karena penghafalan bisa berhasil dengan repitisi dan penguatan (Humdiana, 2005). Dalam bidang pemasaran, brand awareness merupakan faktor yang sangat penting. Konsumen memiliki kesadaran, keakraban, kenyamanan dengan merek yang digunakan.

Berbicara tentang pemasaran adalah berbicara mengenai lingkungan usaha yang selalu menarik untuk diperhatikan oleh para pemasar. Salah satu lingkungan usaha yang permintaan pasarnya selalu meningkat dari tahun ke tahun adalah industri telekomunikasi, khususnya bidang operator seluler. Operator seluler sendiri merupakan kebutuhan yang sangat penting, seiring dengan meningkatnya pertumbuhan penduduk, pendapatan per kapita, pendidikan, teknologi, dan komunikasi, serta berubahnya gaya hidup sosial masyarakat. Industri operator seluler adalah salah satu industri paling maju saat ini.

PT. Telekomunikasi Seluler (Telkomsel) adalah salah satu perusahaan operator telekomunikasi seluler di Indonesia. Salah satu produk kartu seluler yang dimiliki oleh PT. Telkomsel adalah kartu AS. Kartu AS merupakan produk seluler yang membidik segmen pelanggan kalangan milenial (anak muda) Indonesia. Kartu AS pertama kali diluncurkan pada tahun 2004. Kartu AS merupakan salah satu produk perdana yang diluncurkan oleh Telkomsel disamping Simpati dan Kartu Halo. Kartu AS memiliki dua keunggulan yang sangat disukai kalangan anak muda, yaitu harganya yang terjangkau dan murah, serta jangkauan operator yang luas di seluruh Indonesia. Dua hal tersebut mejadi penting karena konsumen mengacu kepada produk yang dirasa dapat memuaskan kebutuhan dan keinginan mereka.

Ada kemungkinan bila perusahaan mengabaikan keunggulan produk, tidak melakukan inovasi dan pengembangan, maka konsumen akan berpindah pada produk pesaingnya, jika hal tersebut terjadi maka perusahaan akan kehilangan pelanggan atau konsumen dan mengakibatkan penjualan akan menurun. Tetapi jika produk dijalankan sesuai dengan keinginan, kebutuhan, dan selera konsumen, serta pangsa pasar yang dibidik, maka diharapkan dapat meningkatkan penjualan produk perusahaan. Mengingat persaingan terus meningkat, maka pihak perusahaan harus meningkatkan kinerja perusahaan termasuk keragaman produk yang ditawarkan, untuk membangun hubungan jangka panjang dengan pelanggannya atau calon pelanggan lain. Produk adalah salah satu unsur bauran pemasaran yang sangat strategis terhadap peningkatan volume penjualan (Kotler, P. \& Lane Kevin Keller, 2008). 
Volume penjualan adalah pencapaian yang dinyatakan secara kuantitatif dari segi fisik, volume atau unit suatu produk. Volume penjualan merupakan suatu yang menandakan naik turunya penjualan dan dapat dinyatakan dalam bentuk unit, kilo, ton atau liter (Rangkuti, 2009). Volume penjualan merupakan jumlah total yang dihasilkan dari kegiatan penjualan barang. Semakin besar jumlah penjualan yang dihasilkan perusahaan, semakin besar kemungkinan laba yang dihasilkan perusahaan. Oleh karena itu volume penjualan merupakan salah satu hal penting yang harus dievaluasi untuk kemungkinan perusahaan agar tidak rugi. Jadi volume penjualan yang menguntungkan harus menjadi tujuan utama perusahaan dan bukannya untuk kepentingan volume penjualan itu sendiri.

Laporan info memo Telkom menyebutkan bahwa ada penurunan 1,50\% atau setara dengan 2,49 juta pelanggan pada kuartal II tahun 2020 dibanding kuartal I tahun 2020. Pada periode ini Telkomsel memiliki 160,07 juta pelanggan. Jika dibanding dengan periode yang sama tahun 2019, jumlahnya turun sekitar 4,60\% atau setara dengan 7,72 juta pelanggan, pada kuartal I tahun 2019 jumlah pelanggan Telkomsel mencapai 167,79 juta pelanggan. Penurunan tersebut dapat tejadi karena dua penyebab, pertama metode pemasaran yang konvensional, dan kedua mudahnya pelanggan beralih ke produk lain. PT. Telkom sebagai perusahaan plat merah banyak menggunakan media televisi untuk pemasaran produk, menjadi sponsor acara di televisi, dan kurang memenfaatkan media sosial untuk pemasaran produk. Dengan persaingan harga paket data seluler yang ketat dan murah antar operator seluler, bisa menjadi faktor pelanggan mudah untuk berpindah penggunaan produk kartu seluler.

\section{Kajian Pustaka}

\subsection{Penjualan Produk}

Penjualan adalah memindahkan posisi pelanggan ke tahap pembelian (dalam proses pengambilan keputusan) melalui penjualan tatap muka (Tjiptono, 2012). Penjualan merupakan tujuan utama dilakukannya kegiatan perusahaan. Perusahaan, dalam menghasilkan barang atau jasa, mempunyai tujuan akhir yaitu menjual barang atau jasa tersebut kepada masyarakat. Oleh karena itu, penjualan memegang peranan penting bagi perusahaan agar produk yang dihasilkannya, dapat terjual dan memberikan penghasilan bagi perusahaan. Penjualan yang dilakukan oleh perusahaan bertujuan untuk menjual barang/jasa yang diperlukan sebagai sumber pendapatan untuk menutup semua ongkos guna memperoleh laba.

Produk adalah segala sesuatu yang dapat ditawarkan ke pasar untuk mendapatkan perhatian, dibeli, dipergunakan, atau dikonsumsi, dan yang dapat memuaskan keinginan atau kebutuhan. Produk mencakup lebih dari sekedar barang berwujud (dapat dideteksi panca indra). Kalau didefinisikan secara luas produk meliputi objek secara fisik, pelayanan, orang, tempat, organisasi, gagasan, atau bauran dari semua wujud diatas (Thamrin \& Francis Tantri, 2013).

Volume penjualan adalah pencapaian yang dinyatakan secara kuantitatif dari segi fisik, volume atau unit suatu produk. Volume penjualan merupakan suatu yang menandakan naik turunya penjualan dan dapat dinyatakan dalam bentuk unit, kilo, ton atau liter (Rangkuti, 2009). Jadi dapat disimpulkan bahwa volume penjualan produk adalah total penjualan yang dinilai dengan unit oleh perusahaan dalam periode tertentu untuk mencapai laba yang maksimal sehingga dapat menunjang pertumbuhan perusahaan. Volume penjualan yang menguntungkan harus menjadi tujuan utama perusahaan dan bukannya untuk kepentingan volume penjualan itu sendiri (Kotler dalam Swastha, 2009). Ada tiga indikator dari volume penjualan, yaitu :

1. Mencapai volume penjualan 
2. Mendapatkan laba

3. Menunjang pertumbuhan perusahaan

\subsection{Digital Marketing}

Digital marketing adalah penerapan teknologi digital yang membentuk online channel ke pasar (website, e-mail, data base, digital TV dan melalui berbagai inovasi terbaru lainnya termasuk didalamnya blog, feed, podcast, dan jejaring sosial) yang memberikan kontribusi terhadap kegiatan pemasaran, yang bertujuan untuk mendapatkan keuntungan dan mempertahankan konsumen (di dalam proses pembelian yang multi-channel dan daur hidup pelanggan), lewat usaha mengenali pentingnya teknologi digital dan mengembangkan pendekatan yang terencana untuk meningkatkan kesadaran konsumen (terhadap perusahaan, perilaku, nilai dan pendorong loyalitas terhadap merek produknya), dan kemudian menyampaikan pesan lewat kegiatan komunikasi dan layanan berbasis online yang terintegrasi dan terfokus untuk memenuhi kebutuhan pelanggan yang spesifik (Chaffey, 2016).

Digital marketing adalah kegiatan pemasaran termasuk branding yang menggunakan berbagai media berbasis web seperti blog, web site, e-mail, adwords, ataupun jejaring sosial. Tentu saja digital marketing bukan hanya berbicara tentang marketing internet (Sanjaya, R. \& Josua Tarigan, 2009). Adapun dimensi dari pemasaran digital dari sisi promosi sebagai bagian dari bauran pemasaran, yaitu (Gumilang, 2019) :

1. Website

2. Optimasi Mesin Pencari (SEO)

3. Periklanan berbasis klik pencarian berbayar (PPC advertising)

4. Pemasaran afiliasi dan kemitraan strategis (affiliate marketing and strategic partnership)

5. Hubungan masyarakat online (Online $P R)$

6. Jejaring sosial (social network)

7. E-mail pemasaran (e-mail marketing)

8. Manajemen hubungan konsumen (Customer Relationship Management)

\subsection{Brand Awareness}

Brand Awareness (kesadaran merek) menunjukkan kesanggupan seorang calon pembeli untuk mengenali atau mengingat kembali bahwa suatu merek merupakan bagian dari kategori produk tertentu (Durianto dkk, 2001). Brand awareness adalah dimensi dasar dalam ekuitas merek. Berdasarkan cara pandang, sebuah merek tidak memiliki ekuitas hingga konsumen menyadari keberadaan merek tersebut (Shimp, 2010).

Tingkatan brand awareness terbagi menjadi empat bagian (Humdiana, 2005), yaitu :

1. Unware of brand (Tidak menyadari merek) ; Kategori ini termasuk merek yang tetap tidak dikenal walaupun sudah dilakukan peningingatan kembali lewat bantuan (aided recall).

2. Brand Recognition (pengenalan merek) ; Kategori ini meliputi merek produk yang dikenal konsumen seteah dilakukan pengingatn kembali lewat bantuan. 
3. Brand Recall (pengingatan kembali merek) ; Kategori ini meliputi dalam kategori sautu produk yang disebutkan atau diingat konsumen tanpa harus dilakukan pengingatan kembali, diistilahkan dengan pengingatan kembali tanpa bantuan (unaided recall).

4. Top Of Mind (Puncak Pikiran) ; Nama merek yang pertama kali diebitkan oleh konsumen dan merupakan puncak dari pikiran dari konsumen itu sendiri.

Berdasarkan kajian pustaka tersebut, hipotesis yang dapat dirumuskan sebagai berikut :

1. Ada pengaruh Digital marketing terhadap Penjualan Produk Kartu AS PT. Telkomsel Branch Palembang.

2. Ada pengaruh Brand Awareness terhadap Penjualan Produk Kartu AS PT. Telkomsel Branch Palembang.

3. Ada pengaruh Digital marketing dan Brand Awareness terhadap Penjualan Produk Kartu AS PT. Telkomsel Branch Palembang.

\section{Metodologi Penelitian}

Populasi adalah keseluruhan subjek penelitian (Suharsimi, 2006). Populasi adalah wilayah generalisasi yang terdiri atas obyek atau subyek yang mempunyai kuantitas dan karakteristik tertentu yang diterapkan oleh peneliti untuk dipelajari dan kemudian ditarik kesimpulan (Sugiyono, 2012). Populasi dalam penelitian ini adalah penduduk Kelurahan Sukarami Palembang yang masuk dalam kategori usia milenial. Kalangan milenial yang dipilih sebagai populasi penelitian bahwa sesuai dengan strategi penjualan kartu AS dari PT. Telkomsel Branc Palembang untuk dapat bersaing dangan operator seluler lainnya, terutama untuk harga paket data internet dan luas jangkauan jaringan operator, yang sering menjadi syarat pilihan konsumen kalangan milenial. Menurut Elwood Carlson dalam buku profil generasi milenial Indonesia (Kemenpppa, 2018) bahwa Usia milenial atau generasi milenial adalah mereka yang lahir dalam rentang tahun 1983 sampai dengan 2001 (usia 19-37 tahun).

Pada penelitian ini sampel yang diambil berdasarkan teknik sampling insidental. Teknik sampling insidental digunakan berdasarkan atas kebetulan saja, yaitu siapa saja yang secara kebetulan/insidental bertemu dengan peneliti dapat digunakan sebagai sampel penelitian apabila orang yang ditemui tersebut cocok dengan sumber data dan kriteria sampel penelitian (Sugiyono, 2012). Pada penelitian ini kriteria responden, yaitu : responden usia 19-37 tahun, memiliki dan memakai produk kartu AS dari PT. Telkomsel. Jumlah populasi penelitian sebanyak 1.274 orang, maka bedasarakan tabel penentuan jumlah sampel penelitian dengan taraf kesalahan $5 \%$, didapat jumlah sampel penelitian sebanyak 270 orang responden.

Desain penelitian yang gunakan adalah penelitian deskriptif kuantitatif dengan metode survey, pengumpulan data penelitian dengan menggunakan kuisioner. Ada tiga kuisioner yang digunakan, yaitu kuisioner digital marketing, kuisioner brand awareness dan kuisioner penjualan produk.

Uji validitas dalam penelitian menggunakan analisis butir (item) yakni dengan mengkorelasikan skor tiap item dengan skor total per konstruk (contruct) dan skor total seluruh item. Output SPSS for windows version 20 menyebutkan bahwa analisis item/butir tersebut dinyatakan sebagai Corrected Item-Total Correlation dan batas minimal untuk menunjukkan item yang valid pada umumnya adalah 0,30 (dapat diterima dan dianggap memuaskan), apabila kurang dari 0,30 maka item tersebut dianggap tidak valid dan tidak memuaskan (Azwar, 2009). 
Sedangkan uji reliabilitas ditentukan dengan koefisien Cronbach Alpha. Pengujian ini menentukan konsistensi jawaban responden/subjek atas suatu instrumen penelitian.

Reliabilitas dinyatakan oleh koefisien reliabilitas yang angkanya berkisar antara 0 samapai dengan 1,00. semakin tinggi koefisien reliabilitas yang mendekati 1,00 maka semakin tinggi pula reliabilitasnya dan sebaliknya. Koefisien reliabilitas yang dapat diterima sebesar 0,90 (Azwar, 2009). Uji hipotesis yang digunakan adalah analisis regresi linear berganda, yang bertujuan untuk mengetahui pengaruh antara variabel bebas dengan variabel terikat yaitu antara variabel digital marketing dan brand awareness terhadap variabel penjualan produk.

\section{Hasil dan Pembahasan}

Hipotesis 1 menyatakan bahwa ada pengaruh digital marketing terhadap penjualan produk KartuAS PT. Telkomsel Branch Palembang. Hasil uji regresi linier sedarhana dengan IBM SPSS version 20 dengan hasil sebagai berikut:

Tabel 3. Hasil Uji Hipotesis 1

Coefficients $^{\mathrm{a}}$

\begin{tabular}{|c|c|c|c|c|c|}
\hline \multirow{2}{*}{ Model } & \multicolumn{2}{|c|}{$\begin{array}{l}\text { Unstandardized } \\
\text { Coefficients }\end{array}$} & \multirow{2}{*}{$\begin{array}{c}\text { Standardized } \\
\text { Coefficients } \\
\text { Beta }\end{array}$} & \multirow{2}{*}{$\mathrm{T}$} & \multirow{2}{*}{ Sig. } \\
\hline & $\mathrm{B}$ & $\begin{array}{l}\text { Std. } \\
\text { Error }\end{array}$ & & & \\
\hline (Constant) & 5,360 & 2,371 & & 2,261 &, 025 \\
\hline Digital marketing & 0,230 & 0,079 & 0,182 & 2,929 & ,004 \\
\hline
\end{tabular}

a. Dependent Variable: Penjualan Produk

Sumber: Hasil Olah Data SPSS-20, 2021

Berdasarkan tabel 3 di atas menunjukan bahwa nilai sig. $t$ sebesar $0,004(p<0.05)$, hal tersebut menunjukan ada nilai signifikan (ada pengaruh). Hipotesis 1 penelitian ini terkait dengan pengaruh faktor digital marketing terhadap penjualan produk kartu AS PT. Telkomsel Branch Palembang. Berdasarkan hasil uji hipotesis 1 di atas, dapat disimpulkan bahwa hipotesis 1 diterima, ini berarti bahwa ada pengaruh signifikan digital marketing terhadap penjualan produk. Digital marketing merupakan faktor penting dalam meningkatkan volume penjualan produk apalagi pada saat-saat sekarang ini di masa pandemi covid-19 diberlakukan kebijakan PPKM (pembatasan pergerakan dan kegiatan masyarakat) yang bertujuan untuk menekan dan mengurangi tingkat penularan virus covid-19. Orang diwajibkan untuk bekerja atau belajar di rumah, dengan demikian konsumsi internet juga meningkat.

Hipotesis 2 menyatakan bahwa brand awareness berpengaruh terhadap penjualan produk. Hasil uji regresi linier sedarhana dengan IBM SPSS version 20 dengan hasil sebagai berikut: 
Tabel 4. Hasil Uji Hipotesis 2

Coefficients $^{\mathrm{a}}$

\begin{tabular}{|c|c|c|c|c|c|}
\hline \multirow{2}{*}{ Model } & \multicolumn{2}{|c|}{$\begin{array}{l}\text { Unstandardized } \\
\text { Coefficients }\end{array}$} & \multirow{2}{*}{$\begin{array}{c}\text { Standardized } \\
\text { Coefficients } \\
\text { Beta }\end{array}$} & \multirow{2}{*}{$\mathrm{T}$} & \multirow{2}{*}{ Sig. } \\
\hline & $\mathrm{B}$ & $\begin{array}{l}\text { Std. } \\
\text { Error }\end{array}$ & & & \\
\hline (Constant) & 5,360 & 2,371 & & 2,261 & 025 \\
\hline Brand Awareness & 0,872 & 0,082 & 0,662 & 10,658 & ,000 \\
\hline
\end{tabular}

a. Dependent Variable: Penjualan Produk

Sumber: Hasil Olah Data SPSS-20, 2021

Berdasarkan tabel 4 di atas menunjukan bahwa nilai sig. $t$ sebesar $0,000(p<0.05)$, berarti signifikan (ada pengaruh), dengan demikian dapat disimpulkan bahwa hipotesis 2 diterima. Ini berarti bahwa ada pengaruh variabel brand awareness terhadap variabel penjualan produk. Hasil penelitian ini membuktikan bahwa brand awareness yang baik akan diikuti dengan peningkatan penjualan produk dan sebaliknya, apabila brand awareness yang dimiliki konsumen buruk akan berimplikasi pada menurunnya penjualan produk.

Hipotesis 3 menyatakan bahwa digital marketing dan brand awareness secara bersama-sama berpengaruh terhadap penjualan produk. Hasil uji regresi linier sedarhana dengan IBM SPSS version 20 dengan hasil sebagai berikut:

Tabel 5. Hasil Uji Hipotesis 3

ANOVA $^{\mathrm{a}}$

\begin{tabular}{|c|c|c|c|c|c|c|}
\hline \multicolumn{2}{|c|}{ Model } & Sum of Squares & Df & Mean Square & $\mathrm{F}$ & Sig. \\
\hline \multirow[t]{3}{*}{1} & Regression & 9117,490 & 2 & 4558,745 & 182,118 & $.000^{\mathrm{b}}$ \\
\hline & Residual & 4931,265 & 197 & 25,032 & & \\
\hline & Total & 14048,755 & 199 & & & \\
\hline
\end{tabular}

a. Dependent Variable: Penjualan Produk

b. Predictors: (Constant), Digital Marketing, Brand Awareness

Sumber: Hasil Olah Data SPSS-20, 2021 
Berdasarkan analisis data pada tabel 5 di atas bahwa nilai sig. $F$ sebesar $0.000(p<0.05)$, berarti signifikan (ada pengaruh). Dengan demikian dapat disimpulkan bahwa hipotesis 3 diterima. Ini berarti bahwa digital marketing dan brand awareness berpengaruh terhadap penjualan produk. Berdasarkan analisi data didapat nilai $\mathrm{F}$ hitung sebesar 182,118 , maka $\mathrm{F}$ tabel $=(\mathrm{k}: \mathrm{n}-\mathrm{k})=2$ : $200-2=0,010$ dengan demikian $\mathrm{F}$ hitung $>\mathrm{F}$ tabel $(182,118>0,010)$ maka dapat disimpulkan bahwa digital marketing dan brand awareness secara bersama-sama berpengaruh terhadap penjualan produk. Diketahui nilai R Square sebesar 0,649. Hal tersebut menggambarkan bahwa digital marketing dan brand awareness secara bersama-sama berpengaruh terhadap penjualan produk sebesar $64,9 \%$. Berarti ada faktor variabel lain sebesar 35,1\% yang mempengaruhi penjualan produk yang perlu dilakukan penelitian lebih lanjut.

Hasil penelitian pada hipotesis 3 (ketiga) di atas, sejalan dengan hasil penelitian Kurniasari, M. dan Budiatmo, A. (2018) yang berjudul Pengaruh Sosial Media Marketing dan Brand Awareness terhadap Keputusan Pembelian Merek J.Co. Donuts \& Coffee di Semarang. Hasil analisis menunjukkan bahwa variabel sosial media marketing dan brand awareness menurut analisa data ternyata berrpengaruh signifikan terhadap keputuaan pembelan. Dari penggunaan media sosial dapat dijadikan peluang oleh para pelaku bisnis untuk menjangkau masyarakat secara real dalam menyampaikan informasi tentang produk yang mereka miliki.

Promosi produk melalui digital marketing, terutama media sosial yang sering diakses oleh kalangan anak muda (milenial), seperti youtube, instagram, facebook, dan twitter pada akhirannya dapat meningkatkan penjualan produk tersebut. PT.Telkomsel Branch Palembang dengan produk kartu AS yang menyasar pelanggan segment milenial, juga memanfaatkan media sosial untuk memasarkan produk kartu AS yang diharapkan dapat meningkatkan penjualan produk Kartu AS. Penjualan produk kartu AS yang dimaksudkan adalah penjualan nilai paket data pada Kartu AS dengan jumlah pemakaian paket data intenet yang dignakan oleh pellanggan/pengguna kartu AS.

\section{Simpulan}

Berdasarkan hasil analisis data penelitian, dapat disimpulkan sebagai berikut:

1. Ada pengaruh signifikan digital marketing terhadap penjualan produk. Digital marketing merupakan faktor penting dalam meningkatkan volume penjualan produk apalagi pada saatsaat sekarang ini di masa pandemi covid-19 diberlakukan kebijakan PPKM (pembatasan pergerakan dan kegiatan masyarakat) yang bertujuan untuk menekan dan mengurangi tingkat penularan virus covid-19. Dengan adanya kebijakan pemberlakukan PPKM, maka masyarakat dianjurkan untuk bekerja dan belajar dari rumah. Banyak aktivitas dilakukan di rumah menyebabkan volume penggunaan internet juga meningkat. Aktivitas penggunaan internt yang tinggi, disaat itulah waktu yang tepat bagi perusahan seluler seperti PT. Telkomsel untuk promosi penggunaaan Kartu AS melalui media digital marketing dalam rangka menarik minat calon konsumen, khususnya kalangan milenial untuk menggunakan Kartu AS produk dari PT. Telkomsel.

2. Berdasarkan hasil analisis hipotesis 2 (kedua) menunjukan bahwa nilai sig. $t$ sebesar 0,000 $(p<0.05)$, dengan demikian dapat disimpulkan bahwa hipotesis 2 diterima. Ini berarti bahwa ada pengaruh signifikan brand awareness terhadap penjualan produk. Hasil penelitian ini membuktikan bahwa brand awareness yang baik akan diikuti dengan peningkatan penjualan produk dan sebaliknya, apabila brand awareness yang dimiliki konsumen buruk akan berimplikasi pada menurunnya penjualan produk. 
3. Berdasarkan analisis data peneitian didaapat bahwa nilai sig. $F$ sebesar $0.000(p<0.05)$, berarti signifikan (ada pengaruh). Dengan demikian dapat disimpulkan bahwa digital marketing dan brand awareness berpengaruh terhadap penjualan produk. Sedangkan hasil nilai $\mathrm{F}$ hitung sebesar 182,118, maka $\mathrm{F}$ tabel $=(\mathrm{k}: \mathrm{n}-\mathrm{k})=2: 200-2=0,010$ dengan demikian $\mathrm{F}$ hitung $>\mathrm{F}$ tabel $(182,118>0,010)$ maka dapat disimpulkan bahwa digital marketing dan brand awareness secara bersama-sama berpengaruh terhadap penjualan produk. Seedangkan nilai R Square sebesar 0,649. Hal tersebut menggambarkan bahwa digital marketing dan brand awareness secara bersama-sama berpengaruh terhadap penjualan produk sebesar $64,9 \%$, Berarti ada faktor variabel lain sebesar $35,1 \%$ yang mempengaruhi penjualan produk yang perlu dilakukan penelitian lebih lanjut.

\section{Referensi}

Azwar, S. (2009). Reliabilitas dan Validitas. Yogyakarta: Pustaka Pelajar.

Bisnis.com. (2020). Jumlah Pengguna layanan Internet di Indonesia. Diakses pada 09 Desember 2020, dari www.bisnis.com

Chaffey, David, dan Fiona Fllis. (2016). Digital Marketing: Strategy, Implementation, and Pratice. United Kingdom: Pearson.

Gumilang, Risa Ratna. (2019). Implementasi Digital Marketing Tehadap Peningkatan Penjualan Hasil Home Industry. e-jurnal Ilmiah Manajemen Vol. 10 No. 1 Edisi Maret 2019. Diakses pada 10 Desember 2020, dari www.journal.ikopin.ac.id

Hundiana. (2005). Strategi Pemasaran. Jakarta:. PT. Gramedia Pustaka Mizan.

Kazali, Rhenald. (2011). Cracking Zone. Jakarta: PT. Gramedia Pustaka Utama.

Kementerian Komunikasi dan Informatka (Kemeninfo). (2020). Penggunaan layanan Internet Pada masa pandemi covid-19. Diakses pada 9 Desember 2020, dari www.kemeninfo.go.id

Kementerian Pemberdayaan Perempuan dan Perlindungan Anak. (2018). Profil Generasi Milenial Indonesia. Diakses pada 9 Desember 2020, dari www.kemenpppa.go.id

Kertajaya, Hermawan. (2008). New Wave Marketing: The World is Still Round The Marketing is Already Flat. Jakarta: PT. Gramedia Pustaka Utama.

Kurniasari, M. \& Budiatmo, A. (2018). Pengaruh Sosal Media Marketing dan Brand Awareness Terhadap Keputusan Pembelian Merekk J.Co. \& Coffee di Semarang. Jurnal Administrasi Bisnis, Vol. 7 No.1, Maret 2018. Diakses pada 10 Agustus 2021, dari www.ejournal.undip.ac.id

Kotler, P. \& Lane Kevin Keller. (2008). Manajemen Pemasaran Jilid 1. Jakarta: PT. Indeks.

Niagahoster.co.id. (2020). Sosial media yang paling banyak digunakan untuk bisnis. Diakses pada 9 Desember 2020, dari www.niagahoster.co.id

Merdeka.com. (2020). Sosial Media yang banyak digunakan di Indonesia. Diakses pada 9 Desember 2020, dari www.merdeka.com

Rangkuti, Freddy. (2009). Strategi Promosi Yang Kreatif, edisi pertama, cetakan pertama, Jakarta : Gramedia Pustaka Utama.

Sanjaya, R. \& Josua Tarigan. (2009). Creative Digital Marketing. Jakarta: PT. Elex Media Komputindo. 
Suharsimi, Arikunto. (2006). Prosedur Penelitian Suatu Pendekatan Praktek. Jakarta: Rineka Cipta.

Sugiyono. (2012). Metode Penelitian Kuantitatif-Kualitatif Dan R\&D. Bandung: Penerbit Alfabeta.

(2012). Statistika untuk Penelitian. Bandung: Penerbit Alfabeta.

Shimp, Terence A. (2010). Integrated Marketing Communication in Advertising and promotion. South Westrn: Cenggage Learning.

Swastha, B., Irawan, Dharmamesta. (2001). Manajemen Pemasaran Modern. Yogyakarta: Penerbit Liberty.

Thamrin, Abdullah dan Francis Tantri. (2013). Manajemen Pemasaran. Jakarta: PT. Raja Grafindo Persada.

Tjiptono, Fandy. (2013). Strategi Pemasaran. Yogyakarta: Andi Offset.

Zuhro, (2010). Good Governance dan Reformasi Birokrasi Di Indonesia. e-jurnal penelitian politik Vol. 7 No. 1 Edisi Agustus 2010, diakses pada 20 Desember 2020, www.ejournal.politik.lipi.go.id 